Jurnal Perikanan (2021) Volume 11. No. $1: 67-78$

DOI : https://doi.org/10.29303/jp.v11i1.173

\title{
PENGARUH PEMBERIAN JENIS PUPUK YANG BERBEDA TERHADAPPERTUMBUHAN DAN KELANGSUNGAN HIDUP RUMPUT LAUT KULTUR JARINGAN (Eucheuma cottoni)
}

\author{
THE EFFECT OF PROVIDING TYPES OF FERTILIZERS THAT DIFFERENT TO THE \\ GROWTH AND SUSTAINABILITY OF THE SEA LIVES OF A NETWORK CULTURE \\ (Eucheuma cottoni)
}

\author{
Muhamad Mahsun Jaelani, Muhammad Marzuki, Fariq Azhar \\ Program Studi Budidaya Perairan Universitas Mataram \\ Jalan pendidikan nomor 37 Kota Mataram
}

Alamat korespondensi : Muhdmahsunjaelani@gmail.com

\begin{abstract}
Abstrak
Rumput laut merupakan salah satu komoditas perikanan yang potensial untuk dibudidayakan. Salah satu rumput laut yang memiliki nilai ekonomi tinggi adalah Eucheuma cottonii yang merupakan hasil kultur jaringan dari spesies alga merah penghasil karagenan dan memiliki banyak peran penting bagi manusia. rumput laut Eucheuma cottonii. Penelitian ini dilakukan pada bulan Maret-April 2019 di laut Lombok Sekotong, Kabupaten Lombok Barat. Metode yang digunakan adalah RAL (Rancangan Acak Lengkap) dengan 4 perlakuan dan 3 ulangan. Media pemeliharaan menggunakan air laut ditambah dengan dosis 100 gram yaitu : P1 (Pupuk Cair), P2 (Pupuk NPK), P3 (Pupuk Urea) P4 (Pupuk TSP). Data yang diamati adalah bobot absolut, panjang absolut, pertumbuhan harian, bobot relatif, panjang relatif dan kualitas air yang digunakan sebagai media pemeliharaan. Analisis data menggunakan ANOVA. Hasil penelitian menunjukkan bahwa penambahan Pupuk Cair, NPK, Urea dan TSP dengan dosis 100 gram berpengaruh sangat nyata terhadap pertumbuhan dan kelangsungan hidup rumput laut Eucheuma cottonii. Laju pertumbuhan tertinggi pada pupuk Urea sedangkan pertumbuhan terendah pada pupuk TSP.
\end{abstract}

Kata Kunci : pertubuhan, rumput laut, pupuk

\begin{abstract}
Seaweed is one of the potential fishery commodities to be cultivated. One of the seaweed that has a high economic value is Eucheuma cottonii which is a result of tissue culture of carrageenan-producing red algae species and has many important roles for humans. seaweed Eucheuma cottonii. This research was conducted in March-April 2019 in the sea of Lombok Sekotong, West Lombok Regency. The method used was RAL (Completely Randomized Design) with 4 treatments and 3 replications. Maintenance media uses sea water added with a dose of 100 grams, namely: P1 (Liquid Fertilizer), P2 (NPK Fertilizer), P3 (Urea Fertilizer) P4 (TSP Fertilizer). The observed data are absolute weight, absolute length, daily growth, relative weight, relative length and water quality used as maintenance media. Data
\end{abstract}


analysis using ANOVA. The results showed that the addition of Liquid Fertilizer, NPK, Urea and TSP with 100 grams dosage had a very significant effect on the growth and survival of Eucheuma cottonii seaweed. The highest growth rate is in Urea fertilizer while the lowest growth is in TSP fertilizer.

Keyword :Seaweed, Fertilizers, Growth

\section{PENDAHULUAN}

Rumput laut merupakan salah satu komoditas perikanan yang potensial untuk dibudidayakan. Salah satu rumput laut yang memiliki nilai ekonomis tinggi adalah Eucheuma cottoniiyang merupakanhasil kultur jaringanspesies alga merah penghasil karagenan dan memiliki banyak peranan penting bagi manusia. Pemanfaatan rumput laut secara ekonomis dimulai tahun 1670 di Cina dan Jepang, yaitu sebagai bahan obatobatan, makanan tambahan, kosmetik, pakan ternak, dan pupuk organik (Ilalqisny dan Widyartini, 2000).

Potensi rumput laut Indonesia memiliki peluang yang sangat baik untuk dikembangkan karena rumput laut memiliki nilai ekonomis tinggi dan permintaan pasar yang besar. Serta yang tidak kalah pentingnya, prospek industri rumput laut sangat bagus karena dapat menghasilkan sekitar 500 produksi akhir yang bisa dihasilkan mulai dari makanan, minuman, kosmetik, hingga obat-obatan. Selain itu rumput laut merupakan salah satu komoditas yang sangat penting bagi kemajuan perikanan Indonesia. Karena Indonesia memiliki potensi areal budidaya yang sangat luas,pada tahun 2013 luas total potensi lahan rumput laut yang masih tersedia yaitu sebesar 769,5 ribu ha, namun hanya sedikit lahan yang sudah dimanfaatkan yaitu hanya mencapai 384,7 ribu ha. Dengan potensi yang dimiliki tersebut pengembangan rumput laut bisa menjadi komoditi unggulan Indonesia (KKP, 2013).

Bibit unggul rumput laut dapat diperoleh dengan melakukan seleksi bibit secara terus menerus, untuk mendapatkan bibit yang adaptif pada lingkungan perairan tersebut. Selain itu, bibit unggul rumput laut dapat diperoleh dari kegiatan kultur jaringan rumput laut di laboratorium (Safirin et al, 2012). Kultur jaringan merupakan suatu metode dalam mengisolasi bagian dari tanaman (pada rumput lautadalahthallus) serta menumbuhkannya dalam kondisi yang aseptik dalam wadah tertutup, sehingga bagian tersebut dapat memperbanyak diri dan bergenerasi menjadi tanaman lengkap kembali seperti induknya (Gunawan, 1897).

Kultur jaringan merupakan teknik untuk memperbanyak tanaman secara aseptik yang ditunjukkan kepada bagian sel atau jaringan suatu tanaman bagiansel atau jaringan dari suatu tanaman, yang dimaksudkan untuk bergenerasi sendiri sehingga tanaman tersebut serupa dengan tanaman induknya (Marisca, 2013).Pada kultur jaringan, implan dapat bergenerasi menjadi embrio somatik setelah ditanam pada media tumbuh (agar). Embrio somatik dapat terbentuk melalui dua cara, yaitu secara langsung maupun tidak langsung melewati fase kalus (Gaj, 2001). Embriogenesis somatik merupakan suatu proses dimana sel somatik (baik haploid maupun diploid) berkembang membentuk tumbuhan baru melalui tahap perkembangan embrio yang spesifik tanpa 
melalui fusi gamet (Hamama et al, 2001). Keunggulan teknik kultur jaringan adalah perbanyakan secara berkesinambungan dan berkualitas tinggi, mempunyai sifat yang identik dengan induknya, dapat diperbanyak dalam jumlah yang besar dengan waktu yang singkat, memudahkan dalam transportasi ke suatu tempat, kesehatan dan mutu bibit lebih terjamin, serta bibit dapat tumbuh dengan cepat menggunakan pupuk (Anonim, 2014).

Penelitian sebelumnya menunjukkanbahwa penambahan pupuk NPK dan urea dengan konsentrasi yangberbeda memberikan pengaruh berbeda sangat nyata $(\mathrm{P}<0,01)$ terhadap pertumbuhan antar perlakuan satu dengan lainnya. Laju pertumbuhan tertinggi $(6,86 \%$ per hari) dicapai pada perlakuan D (NPK 8,26 ppm dan urea 16,26 ppm), sedangkan pertumbuhan terendah $(5,97 \%$ per hari $)$ dicapai oleh perlakuan A (NPK 0 ppm dan urea $0 \mathrm{ppm})$. Oleh sebap itu perlu di lakukan penelitian lanjutan dengan penambahn berbagai jeni pupuk.

Pupuk merupakan bahan yang mengandung sejumlah nutrien yang diperlukanbagi tumbuhan terutama pupuk NPK dan Urea.Penambahan unsur hara berupa pupuk NPK dan urea menjadi alternatif untuk memelihara kesuburan rumput laut terutama rumput laut jenis Eucheuma cottonii, karena kondisi setiap perairan berbeda sehingga kebutuhan nutrien yang baik untuk pertumbuhan rumput laut belum diketahui. PupukNPK merupakan pupuk yang dapat memicu pertumbuhan tunas mudadan meningkatkan daya tahan tumbuhan terhadap serangan penyakit. Pupuk ini mengandung unsur $\mathrm{N}$, unsur $\mathrm{P}$ dan Unsur $\mathrm{K}$ (Anonimous, 2002dalamKushartono etal.,2009). Sedangkan pupuk cair dipercaya lebih baik karena langsung dapat larut dalam air, sehingga dapat langsung digunakan oleh tumbuhan.Pemberian pupuk cair media ENS (Enriched Natural Seawater) dapat memacu pertumbuhan mutlak dan laju pertumbuhan spesifik harian (Aslan, 2003).Menggunakan pupuk organik cair dikarenakan penggunaannya yang lebihramah lingkungan, terjangkau oleh masyarakat dan memiliki kandungan nutrien yang dibutukanrumput laut. Selain itu juga pupuk organik cair telah diterapkan dalam budidaya rumput laut. Dan Penggunaanpemberian pupuk yang mengandung unsur $\mathrm{N}$ seperti urea, ZA dan juga pupuk yang mengandung unsur $P$ seperti TSP dan sebagainya.Dosis yang digunakan 40-50 kg/ha urea dan 15-50 $\mathrm{kg} / \mathrm{ha}$ TSP (Suyanto, 1984). Optimalisasi penggunaan kedua jenis pupuk tersebut (Urea dan TSP) akan sangat menunjang pertumbuhanEucheuma cottonii. Untuk dapat mengetahui tingkat keoptimalannya maka diperlukan penelitian mengenai rasio pupuk Urea dan TSP yang berbeda terhadap pertumbuhan Eucheuma cottoniisehingga didapat informasi tentang rasio Urea dan TSP yang optimal bagi pertumbuhan rumput lautEucheuma cottonii. Sehingga perlu di lakukan penelitian dengan berbagai jenis pupuk dengan jenis pupuk yang berbeda. Penelitian ini bertujuan untuk mengetahui pengaruh pemberian jenis pupuk yang berbeda terhadap pertumbuhan dan kelangsungan hidup rumput laut kultur jaringan (Eucheuma cottoni).

\section{METODE PENELITIAN}

Penelitian ini akan dilaksanakan selama 30 hari mulai pada 6 Maret sampai dengan 6 April 2019 yang bertempat dibalai laut Lombok SekotongKabupaten Lombok Barat. 


\section{Rancangan Penelitian}

Penelitian menggunakan metode RAL ( Ranncangan acak lengkap) dengan 4 perlakuan dan 3kali ulangan yaitu sebagai berikut.

1. Perlakuan (P1)menggunakan pupuk Cair dengan dosis 40 gram.

2. Perlakuan (P2) menggunakan pupuk NPK dengan dosis 40 gram.

3. Perlakuan (P3) menggunakan pupuk Urea dengan dosis 40 gram.

4. Perlakuan (P4) mengunakan TSP dengan dosis 40 gram.

\section{Prosedur Penelitian}

Prosedur penelitian yang akan dilaksanakan selama penelitian adalah sebagai berikut.

\section{Persiapan Bibit Rumput Laut}

Bibit rumput lautyang digunakan berasal darikegiatan kultur jaringan rumput laut di Laboratorium Balai laut LombokSekotong yakni rumput laut jenisEucheuma cottonii berumur 25 - 30 hari dengan bobot 100 gram.

\section{Persiapan Wadah Penelitian}

Wadah yang digunakan dalam penelitian ini berupa toples dengan ukuran 10 liter dengan jumlah 12 unit yang diletakkan pada meja dengan 4 perlakuan dan 3kali ulangan yang dimana pada perlakuan satu (P1)menggunakan pupuk cair, perlakuan dua (P2) menngunakan pupuk NPK, perlakuan tiga (P3) menggunakan pupuk urea (P4) menggunakan pupuk TSP.Kemudian diisi air laut dengan ukuran 10 liter kemudian diamati parameter kualitas air setiap perlakuan dan disesuaikan dengan kualitas air yang sesuai dengan kebutuhanya.

\section{Penimbangan Pupuk}

Pupuk yang digunakan dalam penelitian ini adalah pupuk NPK, pupuk Cair, pupuk Urea, dan pupuk TSP kemudian timbang jenis pupuk tersebut dengan timbangan analitik dengan dosis 40 gram setelah di timbang ke mudian tebar pupuk tersebut pada setiap perlakuan kemudian diamkan selama 3 hari.

\section{Penimbangan Bibit Rumput laut}

Setelah pupuk di diamkan selama 3 hari kemudian di lakukan penimbangan bibit rumput laut dengan timbangan analitik dengan berat bibit rumput laut sebanyak 100 gram kemudian rumput laut di tebar pada setiap perlakuan.

5. Pengontrolan, Pengukuran Panjang dan Berat Rumput Laut, dan Pengukuran Kualitas Air

Pengontrolan dilakukan dilakuan setiap hari kemudian dilakukan pengukuran panjang dan berat rumput laut di lakukan 4 kali selama penelitian dan pengukuran kualitas air rumput di lakukan 4 kali dalam penelitian.

\section{Parameter Penelitian}

Parameter yang diamati selama penelitian meliputi, panjang mutlak, berat spesifik, beratmutlak, panjang relatif, berat relatif dari rumput laut.

\section{Pertumbuhan Panjang Mutlak. \\ Pengamatan dilakuka untuk} mengetahui pertumbuhan panjang rumput laut selama pemeliharaan dari masingmasing perlakuan. Pertambahan panjang mutlak thallus diukur pada awal dan akhir 
penelitiandengan menggunakan penggaris. Pertambahan panjang mutlak thallus dapatdihitung dengan persamaanrumus Effendie (1979) dalam Hidayat (2013):

$\mathrm{L}=\mathrm{Lt}-\mathrm{Lo}$

Keterangan:

$\mathrm{L}=$ Pertumbuhan panjang mutlak $(\mathrm{cm})$

$\mathrm{Lt}=$ Panjang rata-rata akhir $(\mathrm{cm})$

Lo $=$ Panjang rata-rata awal $(\mathrm{cm})$

\section{Laju Pertumbuhan Mutlak}

$$
\text { Pengukuran pertambahan }
$$

beratmutlak rumput laut dilakukan 10 hari sekali selama masa pemeliharaan pertumbuhan mutlak diamati dari awal hingga berakhirnya penelitian, pertumbuhan mutlaklaju berat mutlak dihitung melalui rumus Weatherly (1996) dalam Hidayat (2013).

$\mathrm{W}=\mathrm{Wt}-\mathrm{W} 0$

Keterangan:

$\mathrm{W}=$ Pertumbuhan berat mutlak (gram)

$\mathrm{Wt}=$ Berat rumput laut akhir pemeliharaan (gram)

$\mathrm{W} 0=$ Berat rumput lautawal pemeliharaan (gram)

\section{Laju Pertumbuhan Spesifik}

Pengamatan dilakukanuntuk mengetahui pertumbuhan masing-masing rumput laut pada awal pemeliharaan dan akhir pemeliharaan.

Laju pertumbuhanspesifik dihitung dengan rumus Hariati (1989) dalam Jaya et al. (2012) :

$\mathrm{LP}=\frac{\ln W t-\ln W o}{t} \times 100 \%$

Keterangan:

$\mathrm{LPH}=$ Laju Pertumbuhan Harian; Wt = Berat akhir rumput laut (gram); Wo =

Berat awal rumput laut (gram); $\mathrm{t}=$ Lama waktu pemeliharaan (hari)

\section{Pengukuran Berat Relatif}

Pengukurann dilakuka untuk mengetahui pertumbuhan berat rumput laut selama pemeliharaan dari masing-masing perlakuan tersebut dengan mengukur pertumbuhan relatif (Weatherly and gill,1989 dalam Watimury, 2008).

$\mathrm{H}=\frac{W t-W o}{w o} \times 100 \%$

Keterangan:

$\mathrm{H}=$ Pertumbuhan Nisbi/relatif (gram)

$\mathrm{Wt}=$ Berat akhir setelah $\mathrm{t}$ hari (gram)

Wo $=$ Berat awal (gram)

\section{Pengukuran Panjang Relatif}

Pengukuran dilakukan untuk mengetahui pertumbuhan panjang rumput laut selama pemeliharaan dari masingmasing perlakuan tersebut dengan mengukur pertumbuhanpanjang relatif (Weatherly and gill,1989 dalam Watimury, 2008).

$\mathrm{H}=\frac{W t-W o}{w o} \times 100 \%$

Keterangan:

$\mathrm{H}=$ Pertumbuhan Nisbi/relatif $(\mathrm{cm})$

$\mathrm{Wt}=$ Panjang akhir setelah hari $(\mathrm{cm})$

$\mathrm{Wo}=$ Panjang awal $(\mathrm{cm})$

\section{Pengukuran Kualitas Air}

Pengukuan kualitas air dilakukan degan paramater fisika dan kimia yang dilakukan pada pagi hari dan satu kali seminggu selama 4 minggu selama pemeliharaan rumput laut. Pengukuran kualitas air secara fisika meliputi suhu sedangkan kimia meliputi oksigen terlarut (DO),Salinitas dan $\mathrm{pH}$.

\section{Analisis Data}


Data yang telah dikumpulkan selama proses penelitian dianalisis menggunakan ANOVA (analysis of variance) pada taraf 5\% dan dilakukan uji lanjut BNT (beda nyata terkecil) pada taraf nyata 5\% jika hasil menunjukkan perbedaan yang signifikan.

\section{HASIL DAN PEMBAHASAN}

\section{Pertumbuhan Panjang Mutlak Rumput}

\section{Laut}

Berdasarkan hasil anova menunjukkan bahawa penggunaan pupuk memberikan pengaruh yang nyata terhadap panjang mutlak rumput lautEucheuma cottonii. Hasil uji lanjut menunjukkan bahwa P2 dan P3 tidak berbeda nyata dengan P4, sedangkan P2 dan P3 tidak berbeda nyata. Adapun P1 belum terlihat perbedaanya. Oleh karena itu ,dapat di simpulkan bahwa penngunaan pupuk NPK (P2) dan pupuk Urea (P3) memberikan nilai panjang mutlak yang paling baik dibandingkan menggunakan pupuk TSP
(P4) . Hal ini ditunjang oleh kandungan $\mathrm{N}$ pada perlakuan P3dan P2 yakni pupuk Urea dan NPK lebih banyak dan juga jaringan thallus masih muda sehingga memberikan pertumbuhan yang optimal. Hendrajat (2008) menyatakan bahwa adanya kenaikan pertumbuhan panjang menunjukkan bahwa pertumbuhan panjang rumput laut sudah memasuki tahap perpanjangan sel, karena tersedianya unsur hara yang cukup untuk pertumbuhan di karenakan jumlah nitrogen yang tinggi berpengaruh terhadap pertumbuhan (berat dan panjang) rumput laut. Hal tersebut sesuai dengan pendapat Novizan (2000) dalamLatif (2008) bahwa pupuk nitrogen di dalam perairan menyebabkan tanaman tumbuh subur, sehingga produksinya akan meningkat. Selain itu, nitrogen merupakan komponen yang sangat penting untuk pertumbuhan thallus rumput laut Selain unsur N, rumput laut juga membutuhkan unsur phospat (P) untuk pertumbuhannya.

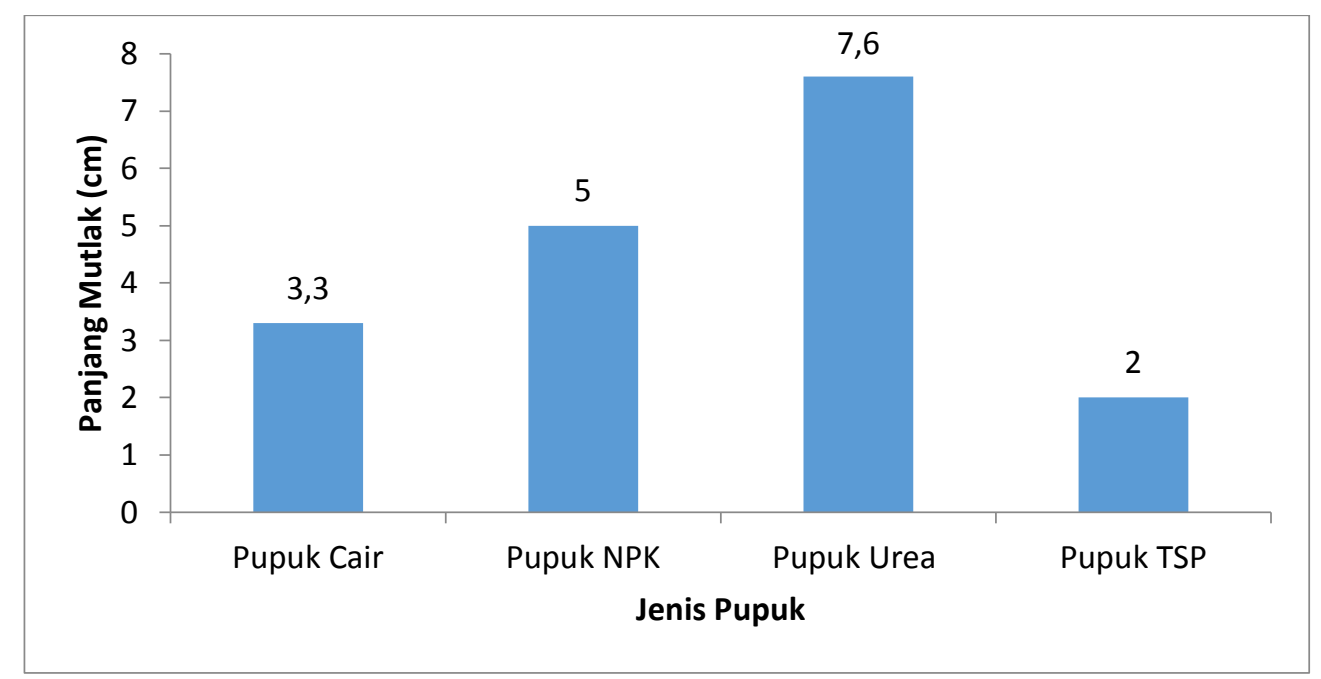

Gambar 1. Pertumbuhan Panjang Mutlak Rumput Laut E. Cottonii

Dari hasil uji lanjut rentang perlakuan P1, P2, P3 dan P4 hasilnya memiliki notasi yang berbeda, menunjukan bahwa pengaruh jenis pupuk berbeda nyata terhadap pertumbuhan panjang mutlak rumput laut Eucheuma cottonii. Dari hasil penelitian yang di lakukan selama 30 hari.Jadi dapat di katakan bahwa perbedaan 
pupuk sangat mempengaruhi pertumbuhan panjang rumput lautEucheuma cottonii.

\section{PertumbuhanBerat Mutlak Rumput}

\section{Laut}

Berdasarkan hasil anova

menunjukkan bahwa penggunaan pupuk

memberikan penagaruh yang nyata terhadap berat mutlakrumput laut

Eucheuma cottonii. Hasil uji lanjut menyatakan bahwa P3 berbeda nyata dengan P4 dan P1, sedangkan P4 dan P1,tidak berbeda nyata. Adapun P2 masih belum terlihat jelas perbedaanya. Sehingga dapat di simpulkan bahwa pertumbuhan mutlak yang paling baik adalah dengan menggunakan P3 yaitu pupuk Urea dibandingkan dengan menggunakan pupuk TSP (P4) dan pupuk Cair (P1).Urea merupakan jenis pupuk tunggal yang unsur nitrogennya berfungsi untuk mempercepat pertumbuhan thallus (Doty,2002).

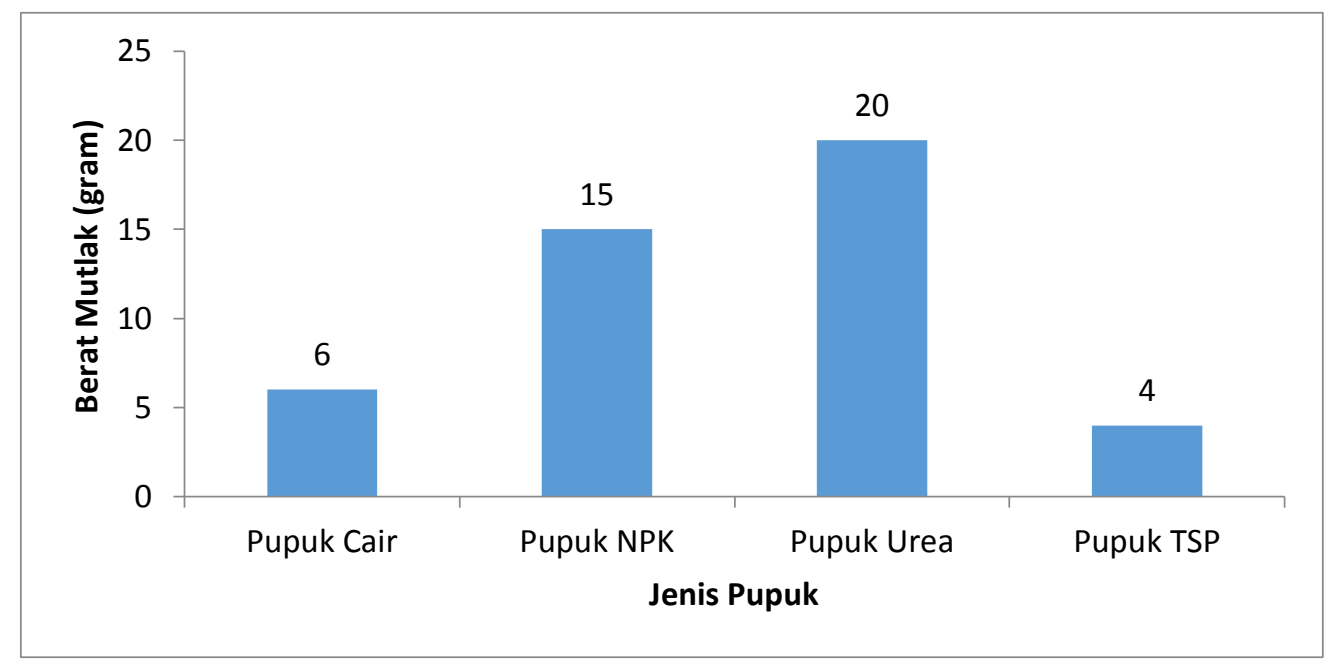

Gambar 3. Pertumbuhan BeratMutlak Rumput LautEucheuma cottonii

Disamping itu pupuk urea merupakanpupuk yang mudah diserap tumbuhan pada keadaantergenang yaitu saat larut dalam air (Novizan, 2002). Pupuk urea merupakan jenis pupuk yangsangat mudah ditemukan di pasaran karena unsur yang terkandung dalam pupuk ini sangat bermanfaat bagi pertumbuhan rumput laut Eucheuma cottonii. Pupukurea ini jenis pupuk tunggal yangunsur nitrogennya berfungsi

mempercepatpertumbuhanthallus.Pupuk ureamerupakan jenis pupuk yang sangat mudahdiserap karena unsur yangterkandung dalam pupuk ini sangat bermanfaat bagi pertumbuhan rumput laut.

\section{Laju Pertumbuhan Spesifik Rumput Laut}

Hasil anova menunjukkan bahwa penggunaan pupuk memberikan pengaruh yang nyata terhadap berat spesifik rumput laut Eucheuma cottonii. Hasil uji lanjut menunjukkan bahwa P3 berbeda nyata dengan P4. Adapun P1 dan P2 tidak terlihat perbedaanya. Interpretasi berdasarkan uji lanjut ini adalah penngunaan pupuk Urea (P3) lebih baik di bandingkan pupuk TSP (P4) dalam peningkatan berat spesifik.. Hal ini diduga pada perlakuan P3 mempunyai kandungan $\mathrm{N}$ tertinggisehingga pertumbuhan akan lebih cepat disbandingperlakuan lain. Pada rumput laut Eucheuma cottonii, thallusakan tumbuh lebih besar. Oleh sebab itudiduga besarnya 
thallus dan luasnya penampangtubuh fotosintesissebanding dengan jumlah rumput laut yang tersedia untuk nitrogen yang diberikan(Sarief, 1986).

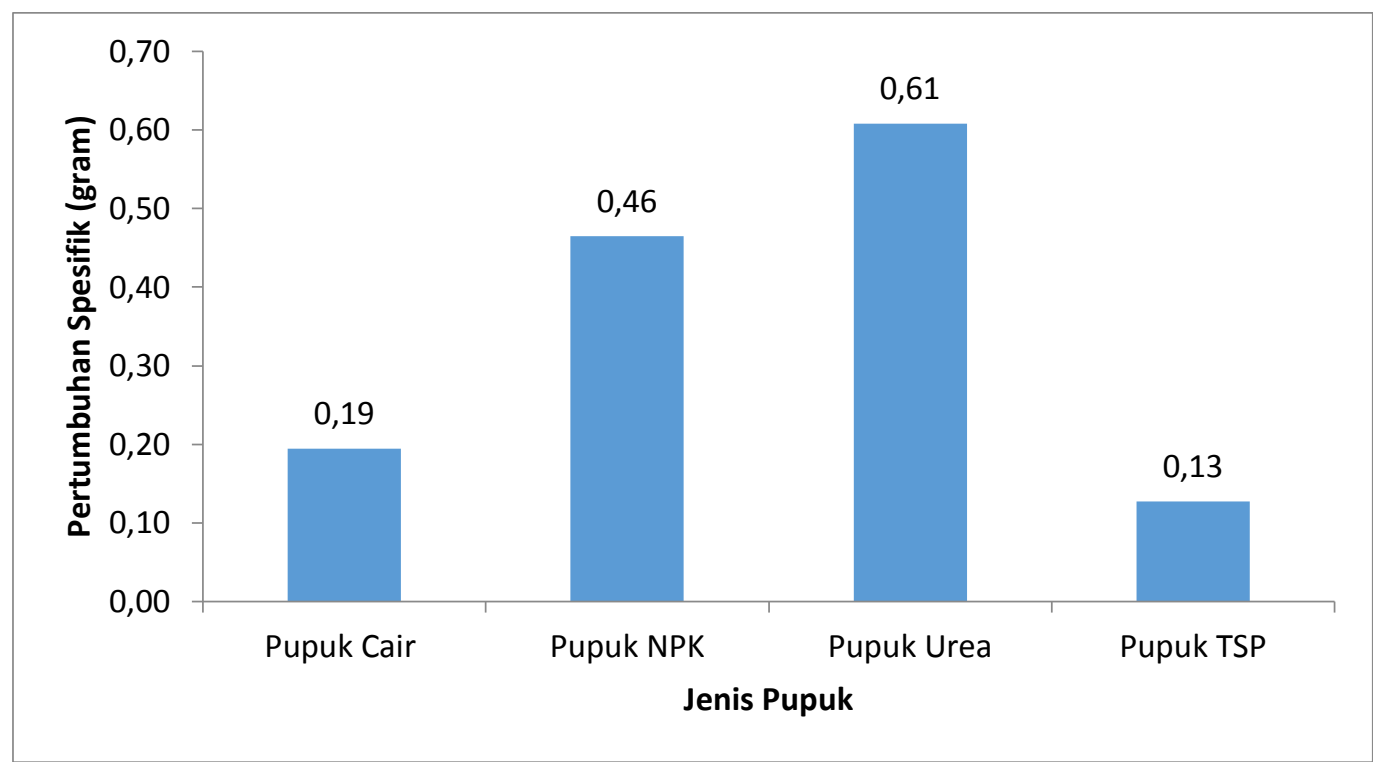

Gambar 2. Pertumbuhan Spesifik Rumput LautEucheuma cottonii

Menurut Doty (1987), laju pertumbuhan padabudidaya Eucheumacottoniiberkisar $2-10 \%$ per hari tergantung kualitas air dan lingkungannya. Eucheumacottonii berkualitas baikakan menghasilkan laju pertumbuhan yang baik dan tingginya Kualiatas air sangat mempengaruhi pertumbuhan rumput laut terutama rumput laut Eucheuma cottoniiDengan demikian, budidaya rumput laut Eucheuma cottonii dipengaruhi oleh kondisi air laut yang sangat menentukan kualitas produksi. Hal ini sesuai dengan pandangan Trono (1983) bahwa distribusi dan pertumbuhan rumput laut Eucheumacottonii tidak terlepas dari adanya intensitas cahaya dan suhu yang memungkinkan terjadinya gerakan partikelpartikel air laut di bagian permukaan maupun di daerah yang dalam. Kondisi air laut yang penting dalam kegiatan budidaya rumput laut.

\section{Panjang Relatif Rumput Laut Eucheuma cottonii}

Hasil anova menunjukkan bahwa penggunaan pupuk memberikan pengaruh yang nyata terhadap panjang relatif. Hasil uji lanjut menunjukkan bahwa P2 dan P3 berbeda nyata dengan P4, sedangkan P2 dan P3 tidak berbeda nyata. Adapun P1 tidak terlihat perbedaanya. Sehingga dapat disimpulkan bahwa penggunaan pupuk NPK (P2) dan pupuk Urea (P3) memberikan panjang relatif yang lebih baik dibandingkan menggunakan pupuk TSP (P4). Hal ini diduga pada Perlakuan tersebut, kebutuhan nutrien dapat tercukupi dengan baik.Nutrien pada penelitian ini tercukupi oleh pupuk NPK dan urea yang merupakan sumber komponen penting dalam pertumbuhan rumput laut. Hal ini sesuai pendapatWeatherly (2002) bahwa pupuk Urea, NPK dan pupuk Cair merupakan pupuk yang dapat memicu pertumbuhan tunas muda dan dapat meningkatkan daya tahan tumbuhan terhadap serangan penyakit. Pupuk ini mengandung unsur $\mathrm{N}$, unsur $\mathrm{P}$ dan unsur $\mathrm{K}$. Nitrogen merupakan komponen penting 
bagi pertumbuhan rumput laut. Pantjara dan Sahib (2008), yang menyatakan bahwa nitrogen berfungsi membantu proses pembentukan klorofil dan fotosintesis. Sedangkan fosfat yang terkandung dalam pupuk NPK berfungsi merangsang pertumbuhan thallus.Pupuk NPK, Urea dan Cair merupakan jenis pupuk yang sangat mudah ditemukan di pasaran karena unsur yang terkandung dalam ketiga pupuk ini sangat bermanfaat bagi pertumbuhan rumput laut Eucheuma cottoniipenambahan pupuk NPK, Urea, dan Cair dengan dosis 100 gram pada budidaya rumput lautEucheuma cottoniidigunakan untukmengetahui konsentrasi pupuk yang tepat untuk pertumbuhan panjang rumput laut Eucheuma cottonii .

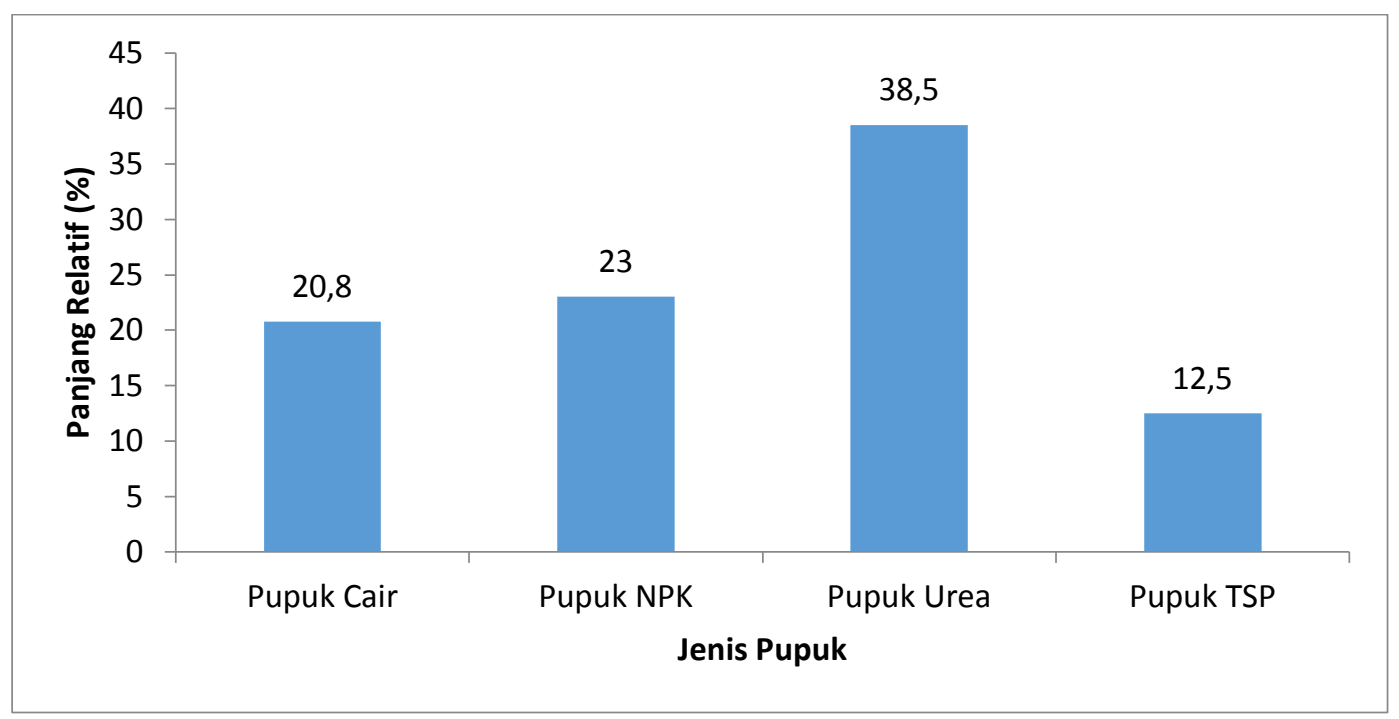

Gambar 4. Panjang Relatif Rumput LautEucheuma cottonii

\section{Berat Relatif Rumput Laut Eucheuma cottonii}

Hasil anova menunjukkan bahwa pnngunaan pupuk memberikan pengaruh yang nyata terhadap berat relatif. Hasil uji lanjut menunjukkan bahwa P3 berbeda nyata dengan P4. Adapu P1 dan P2 tidak terlihat perbedaanya. Interpretasi berdasarkan uji lanjut ini adalah penggunaan pupuk Urea (P3) lebih baik dalam peningkatan berat relatif dibandingkan pupuk TSP (P4.Hal tersebut diduga disebabkan oleh kandungan pupuk padaperlakuan P3 mempunyai nilai $\mathrm{N}$ paling tinggi dibandingkan dengan perlakuan yang lain. Pada dasarnya unsur yang banyak dibutuhkan oleh rumput laut adalah unsur N. Nitrogen ini diperlukan sebagai penyuplai energi dalam proses fotosintesis. Menurut Kuhl (1974) nutrisi utama yangdibutuhkan rumput laut adalah Nitrogen (N), Fosfor (P) dan Kalium (K), dengan Dosis 100 gr (Round, 1977). Hal ini sesuai dengan perlakuan P3 yang mempunyai unsur $\mathrm{N}$ tertinggi. Selain itu juga mempunyai perbandingan yang sesuai antara unsur $\mathrm{N}$ dan $\mathrm{P}$ dimana ketersediaan unsur $\mathrm{N}$ tiga kali lebih besar dibandingkan unsur P. Tidak terpenuhinya salah satu unsur akan mengakibatkan menurunnya kualitas dan kuantitas hasil produksi. Unsur $\mathrm{N}$ merupakan unsur makro yang bermanfaat untuk memacu pertumbuhan dan jika kekurangan unsur $\mathrm{N}$ akan menghambat pertumbuhan, dimana hasil tertinggi pada perlakuan III dengan konsentrasi $\mathrm{N}$ tertinggi. 


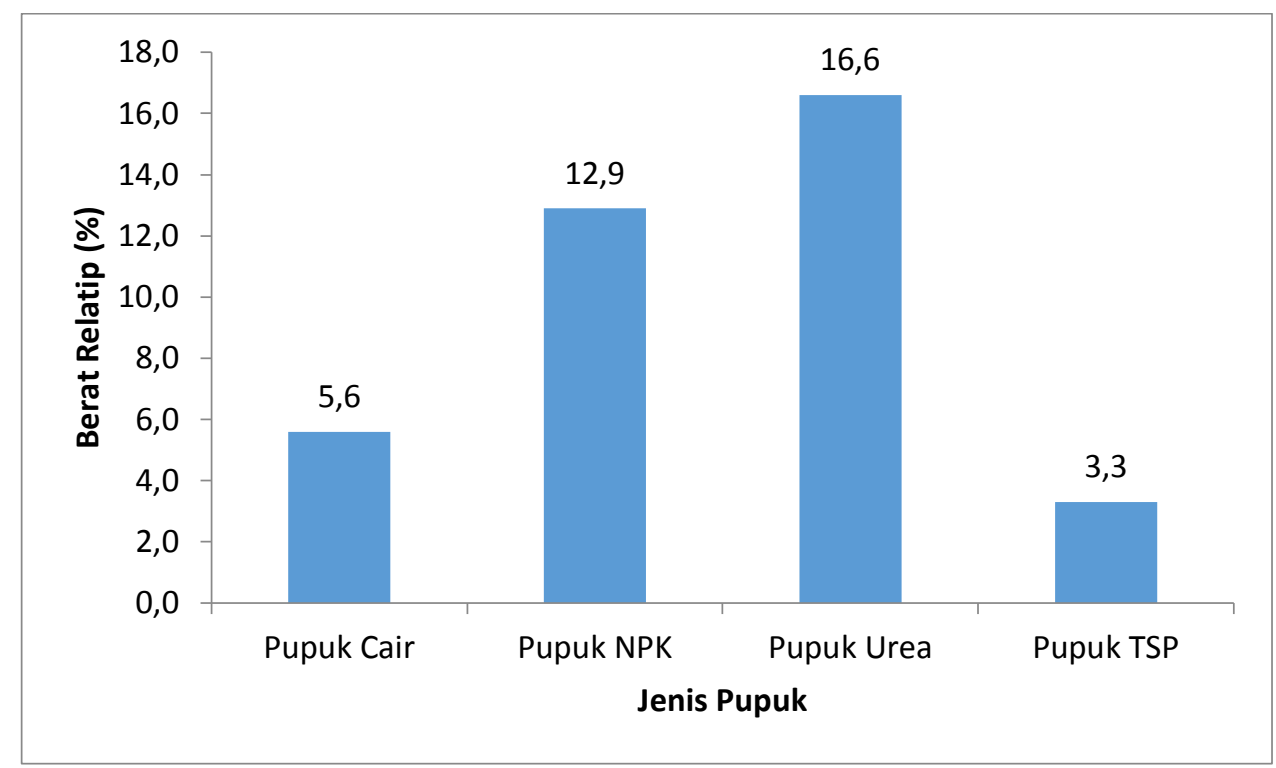

Gambar 5 . Berat Relatif Rumput LautEucheuma cottonii

Kualitas Air Rumput Laut Eucheuma

\section{Cottonii}

Tabel 3. Parameter Kualitas Air

\begin{tabular}{cccc}
\hline No & Parameter & Hasil & Refrensi \\
\hline 1 & Suhu $\left({ }^{\circ} \mathrm{C}\right)$ & 29,5 & $\begin{array}{c}28^{\circ} \mathrm{C}-30{ }^{\circ} \mathrm{C} \\
(\text { Fuadiyah, 1991) }\end{array}$ \\
\hline 2 & $\mathrm{pH}$ & 7,3 & $\begin{array}{c}>6,75 \text { (Winanto, } \\
2004)\end{array}$ \\
\hline 3 & $\begin{array}{c}\text { Salinitas } \\
(\%)\end{array}$ & 30 & $\begin{array}{c}29-35(\text { Sutaman, } \\
1993)\end{array}$ \\
\hline 4 & DO & 7,2 & $\begin{array}{c}4,4-72(\text { Aslan, } \\
1991)\end{array}$ \\
\hline
\end{tabular}

Selama penelitian suhu air diukur pada pagi dan sore hari. Suhu air media pemeliharaan diatur dengan sistem penerangan yang kontinyu, disamping itu juga dipasang aerasi. Menurut Hastuti (1988) dalamFuadiyah (1991), manfaat dari aerasi selain untuk melarutkan oksigen dalam air, juga untuk mencegah terjadinya stratifikasi, sehingga perbedaan suhu dapat dihilangkan. Suhu air akan berpengaruh secara tidak langsung maupun secara langsung terhadap laju pertumbuhan maupun kelangsungan hidup rumput laut Eucheuma cottonii. Harvey. Hasil pengukuran suhu selama penelitian berkisar antara $26-280 \mathrm{C}$, dari kisaran suhu tersebut masih layak bagi pertumbuhanrumput laut Harvey. Menurut Aslan (1991), dan Achmad Kadi (1988), bahwa rumput laut Eucheuma cottonii. Harvey tumbuh dengan baik pada suhu air antara $25-300 \mathrm{C}$, tetapi terhambat pada kombinasi suhu rendah da intensitas cahaya tinggi.

$$
\text { Menurut Fogg }
$$
dalamFuadiyah (1991), bahwa derajat keasaman secara langsung berperan dalam kegiatan enzim dan secara tidak langsung berperan dalam menentukan konsentrasi karbondioksida dan imbangan antara karbonat dan bikarbonat. Dari hasil pengukuran derajat keasaman selama pemeliharaan didapat kisaran $\mathrm{pH}$ antara 6,2 - 8,3. Hal ini disebabkan karena adanya pemberian pupuk sehingga menyebabkan perairan menjadi kaya $\mathrm{CO} 2$ yang akan digunakan dalam proses fotosintesa, Dari kisaran tersebut rumput laut atau alga masih dapat mentoleransi mengingat air media selama penelitian tidak diganti dan wadah 
yang digunakan sangat kecil dengan volume air 2 liter. Dalam Anonymous (1992), derajat keasaman $(\mathrm{pH})$ air optimum berada pada kisaran antara 8,2-8,7.

Menurut Nyan Taw (1990) dalamFuadiyah (1991), bahwa oksigen terlarut(DO) merupakan faktor yang esensial bagi fitoplankton untuk proses fotosintesa. Kandungan oksigen terlarut (DO) dari hasil penelitian selama pemeliharaan berkisar antara 4,4-7,2 ppm. Kisaran ini sangat layak untuk pertumbuhan rumputlaut Eucheuma cottonii. Haervey. Menurut Aslan (1991), bahwa kisaran oksigen terlarut (DO) yang dibutuhkan untuk pertumbuhan rumput laut Eucheuma cottonii. Harvey berkisar antara 3-8 ppm.

\section{KESIMPULAN DAN SARAN}

\section{Kesimpulan}

Panjang mutlak dan panjang relatif terbaik didapatkan dengan penggunaan pupuk jenis NPK (P2) dan jenis pupuk Urea (P3). Adapun untuk parameter pertumbuhan yang lain seperti berat mutlak, berat relative dan berat spesifik, penggunaan pupuk jenis Urea (P3) lebih baik dari pupuk jenis TSP (P4). Pupuk jenis TSP (P4) bemberikan nilai yang paling buruk untuk seluruh parameter pertumbuhan rumput laut Eucheuma cottonii.

\section{Saran}

Untuk memberikan profil
pertumbuhan yang paling baik, pembudidaya rumput laut Eucheuma cottoniidapat menggunakan pupuk jenis Urea (P3). Pupuk jenis Urea (P3) secara konsisten telah memberikan nilai yang paling baik pada seluruh parameter pertumbuhan yang dianalisis.

\section{DAFTAR PUSTAKA}

Anonimous. 2002. Penerapan Best Management Practices (BMT) pada Budidaya Udang Windu (Penaeus monodon Fabricus) Intensif. Departemen Kelautan dan Perikanan, Direktorat Jenderal Perikanan Budidaya: Balai Besar Pengembangan Budidaya air Payau. Jepara.

Aslan. 2003. Petunjuk Teknis Budi Daya Rumput Laut. [Skripsi, unpublished]. Bogor:Institut Pertanian Bogor.

Doty, 1973.Pemeliharaan Rumput Laut Jenis Kappaphycus Alparizi Dengan Menggunakan Metode Pertikultur Pada Berbagai Kedalaman dan Berat Bibit Awal yang Berbeda Di Perairan Desa Langkule Kecamatan Gu Kabupaten Buton. Skripsi. Jurusan Perikanan Universitas Haluoleo.

Effendie. 1979. Petunjuk Teknis Budidaya Rumput Laut.Puslitbangkan Jakarta . Indonesia.

Gaj. 2001. Studi Penentuan Lokasi Untuk Pengembangan Budidaya Laut Berdasarkan Parameter Fisika, Kimia dan Biologi di Teluk Kupang, Nusa Tenggara Timur. [Thesis,unpublished]. Universitas Diponegoro. Semarang. Indonesia.

Gunawan. 1987.Pengamatan Penyakit iceice dan alga competitor fenomena penyebap kegagalan panen budidaya rumput laut. Makalah Seminar Nasional RIPTEK kelautan Nasional. Jakarta, 30-31 Juli 2003. 
Hamama. 2001. Analisis Daya Saing Rumput Laut Indonesia di Pasar Internasional. [Skripsi, unpublished]. Institut Pertanian Bogor. Bogor. Indonesia.

Hariati. 1989. Pengendalian Penyakit IceIce Untuk Peningkatkan Produksi Rumput Laut Indonesia. Jurnal Saintek Perikanan 3 (2): 37 - 43.

Hidayat. 2003. Kajian Pertumbuhan Rumput Laut. Kelautan Universitas Diponogoro. Semarang Jurnal Penelitian.

KKP. 2013. Pertumbuhan Rumput Laut Kappaphycus Alparizi Pada Perbedaan Kedalaman Dan Berat Awal Di Perairan Talengan Kabupaten Kepulauan Sangihe; Sulawesi Utara. Jurnal Penelitian.

Kushartono. 2019. Percobaan Budidaya Rumput Laut di Perairan Lorok, Pacitan dan Kemungkinan
Pengembangannya. Bull. Pen. Perikanan, I(2): 157-166

Marisca.2013. Pengenalan Jenis Alga Merah. Di dalam: Pengenalan Jenis- Jenis Rumput Laut Indonesia. Pusat Penelitian dan Pengembangan Oseanologi. Lembaga Ilmu Pengetahuan Indonesia. Jakarta.

Novizan. 2000.Budidaya dan Pengelolahan Rumput Laut. Agromedia Pustaka; tanggerang.

Safirin. 2012. Percobaan Budidaya Rumput Laut di Perairan Lorok, Pacitan dan Kemungkinan Pengembangannya. Bull. Pen. Perikanan, I(2): 157-166

Sarief. 1986.Novizan. 2000.Budidaya Rumput Laut Gracilaria verrucosa di Pertambakan denganPerbedaan Waktu Perendaman di Dalam Larutan NPK. Agromedia Pustaka; tanggerang. 